\title{
Does Corporate Governance Matter in Meeting and Beating Analysts' Forecasts
}

\author{
Soumaya Ben Malek Maztoul ${ }^{1}$ \\ ${ }^{1}$ High School of Business, Tunisia \\ Correspondence: Soumaya Ben Malek Maztoul, High School of Business, Tunisia. E-mail: \\ maztoulsoumaya@yahoo.fr
}

Received: November 12, 2013

Accepted: December 18, 2013

Online Published: January 23, 2014

doi:10.5539/ijbm.v9n2p276

URL: http://dx.doi.org/10.5539/ijbm.v9n2p276

\begin{abstract}
Meeting and beating analysts' forecast has received substantial attention, most of studies investigate two principles problems: the valuation and value relevance of meeting and tools used to achieve benchmarks. This research is different, we investigate whether internal corporate governance impacts on meeting and beating analysts' forecasts and consistently do it, we also examine if these attributes alleviate opportunistic behavior.

This paper contributes to the growing literature on earnings benchmarks, it targets to be more specified than previous ones by considering governance attributes without an index. Using a logistic regression models, we document that 'small' institutional investors and incentive compensation incite managers to meet analysts' forecasts contrarily to debt and board activity. We find that consistently meeting is harder to realize and affected by governance attributes. Moreover, results indicate that stock options are associated with opportunistic managerial activities while institutional ownership temperate it.

This study is important for investors who must be more attentive about financial signals like meeting analysts' forecasts that may be affected by opportunistic managerial behavior. Furthermore, findings indicate that regulation affect this tendency which reveal the importance of regulators in increasing the transparency of financial market.
\end{abstract}

Keywords: meetings analysts forecasts, governance, opportunism

\section{Introduction}

Meeting analysts' forecasts was widely criticized by empirical research and financial press, making it a reason of illusions' investor. Studies argue that analysts' forecasts become a benchmark, Brown and Caylor (2005) document an increase of meeting or beating forecasts during 1994-2001, managers seek to avoid negative quarterly earnings surprises more than others thresholds i.e. losses and earnings decreases. Companies are not only interested by meeting analysts' forecasts but also by consistently do it. Vickers (1999) signals that more than $17 \%$, of studied companies, realized analysts' forecasts at least nine of the past twelve quarters between 1996 and 1999.

It's important to meet forecasts since it allows maximizing share price (Bartov, Givoly \& Hayn, 2002). However, if stock price becomes grossly overvalued, this may lead to an adverse effect on subsequent performance; to harm the firm or, in some cases, to completely destroy it. This overvaluation has been exacerbating by the breakdown in the control agency problems within the gatekeepers, most notably investment banks and auditing firms (Jensen, 2004). Thus, we have to point out the role of corporate governance in such problem. In fact, governance mechanisms set up a system to control executive director to protect shareholders. Nevertheless, when these mechanisms are inefficient, pressures inevitably push manager to undertake risky actions for justifying high price and growth, this can destroy value (Fuller \& Jensen, 2002), which may be the case for strategies to meet analysts' forecasts.

This paper investigates which and how corporate governance attributes are associated with meeting and consistently meeting and beating analysts' forecasts and whether they alleviate opportunistic managerial behavior. We argue that institutional investors and incentive compensation are positively associated with the likelihood to meet and consistently meet and beat analysts' forecast. Stock options have a considerable effect on opportunistic managerial attitude contrarily to block institutional investors. 
Motivation for this paper comes from the documented pressure exercised on CEOs to meet and even beat forecasts; we think that this can influence managers actions given the importance assigned to this tendency it by investors and financial community. Moreover, attention to this trend increased over accounting scandals given the assumed role to analysts in this crisis but also to corporate governance mechanisms.

This paper provides further evidence on cross-sectional differences in incentives and constraints to avoid negative earnings surprise both in short and long run terms. It explores associations of firms' specific characteristics with meeting and consistently meeting and beating analysts' forecasts.

This study contributes to the literature that investigates pessimistic bias in analysts' forecasts in association with governance attributes that isn't widely explored. In fact, most of prior studies have focused on valuation and financial market consequences. Interestingly, we explore some governance mechanisms without using governance index to have clearer idea for which and how a corporate governance mechanism affect meeting expectations.

In the next section, we expose related literature. Thereafter, we describe research design and provide descriptive statistics. After this, empirical evidence of the association between governance attributes and the likelihood of meeting or beating expectations are exposed with additional and sensitivity tests. In the end, we expose concluding remarks and suggestions for future research.

Literature review and hypothesis development

Many reasons encourage CEO to meet analysts' forecasts, the most important is the maximization of share price, Bartov et al. (2002) document a market premium (penalty) to meet or beat (failing to meet) analysts' forecasts. Moreover, meeting permits to have good relations with partners, to avoid implicit claims with stakeholders (Matsumoto, 2002), to avoid restrictions debt (Jiang, 2008), and to maximize compensation (McVay, Nagar \& Tang, 2006).

In another hand, control mechanisms attempt to restrict CEO's power and influence his decisions. Managers of well governed firms have less discretion; they will not abuse their power to show an imaginative performance. According to Shleifer and Vishny (1997), governance mechanisms are economic and legal institutions, providing investors with the proper use of their capital to protect them of undervaluation and overvaluation. Firm's governance structure is useful in assessing the credibility and quality of financial information. Thus, our first hypothesis is:

$\mathrm{H}_{1}$ : Governance mechanisms affect the likelihood of meeting analysts' forecasts.

We would explicitly study the relationship of each governance attribute with meeting and beating analysts' forecasts. For this, we classify internal mechanisms into three categories; capital structure, incentive compensation and control committees.

Capital structure and forecasts' meeting

Agency theory assumes that the ownership structure is an effective control of directors; it encourages controllers to perform their functions with lower cost. The presence of institutional investors in the capital is a mean of effective monitoring of CEO' actions motivating him to invest in long-term projects (Wahal \& McConnell, 2000). Previous studies focused on analysts following and institutional ownership, the pioneering study of Bhushan (1989) identifies positive relationship between them; while Matsumoto (2002) finds a positive effect of institutional ownership and meeting quarterly forecasts.

Indeed, institutions have resources, capabilities and opportunities to control CEO to focus more on long-term values appreciation, institutions with a substantial investment in the firm are encouraged to control further the CEO. Contrarily, smaller or transient institutional investors can have short-term goals given their lower ownership; they will be less interested in an efficient and expensive control. They focus on the short term and require leadership to do so (Bushee, 1998). More recently, Shanthikumar (2012) indicates that small traders' reaction becomes more negative over a series of negative surprises. So, our hypothesis is:

$\mathrm{H}_{1.1}$ : Given their ownership, institutional investors affect differently the likelihood of meeting analysts' forecasts.

Besides institutional investors, managers may have a stake in firm. Few studies are concerned by the relationship between managerial ownership and analysts' forecasts. For, Chen and Steiner (2000), managerial ownership and analysts following affect positively firm performance. McVay et al. (2006) suggest that CEOs who plan to sell their short-term securities are more likely to meet analysts' expectations. More recently, Baik, Kang and Morton (2010) conclude that managerial entrenchment leads to information opacity, reducing forecast 
accuracy and discouraging analyst coverage.

Meeting forecast is an important purpose for CEO, that's why we are interesting particularly by CEO ownership. Current studies are focusing on the relationship of CEO ownership and the firm value (Tong, 2007), performance (McClelland, Barker III \& Oh, 2012), institutional ownership (Shin, 2005).

$\mathrm{H}_{1.2}$ : CEO ownership increases the likelihood of meeting analysts' forecasts.

We also focus on debt since it's also an effective mean of control. Grossman and Hart (1982) suggest that debt is an incentive for the CEO to adopt effective management and choose the right investment decisions; it limits managerial discretion by reducing access to cash flow. Stulz (1990) confirms that regular payment of interest and repayment of debt can limit aberrant practices of CEO in the use of cash for the firm.

Some research focused on the relationship between analysts' forecasts and debts. Barton and Simko (2002) confirm that less leveraged firms have higher sensitive coefficients to results which make managers more inclined to meet analysts' forecasts. More recently, Jiang (2008) documents that firms performing benchmarks have a better ranking and bond's spread. Although, reduction in a firm's cost of debt associated with reporting profits equals or exceeds the effects associated with reporting an earnings increase and beating analysts' forecasts.

We add that creditors are sophisticated and knowledgeable agents; unlike investors, they have a fixed value in the company, they bear the risk of lower performance but do not share the benefits of increased growth, thus their primary concern is making a profit, they are less interested in meeting of analysts' forecasts. Our next hypothesis is:

$\mathrm{H}_{1.3}$ : Debt decreases the likelihood of meeting forecasts.

\subsection{Incentive Compensation and Forecasts' Meeting}

Fuller and Jensen (2002) attribute forecasts' meeting to favorable market conditions and compensation philosophy. Indeed, change in executive compensation structure in the United States has prompted the CEO to deliver the "Expectation Game".

According to Imhoff and Lobo (1984), the analysts' forecasts are reflected in the directors' expectations. CEOs are encouraged to moderate expectations via analysts' forecasts to set performance thresholds of their relatively small bonus. In addition, the way in which the company revises its bonus plans, based on accounting performance, may encourage managers to distort their performance. Matsunaga and Park (2001) show that it's advantageous for the CEO to meet three of the four quarterly forecasts, since otherwise bonus may fall of $21 \%$. However, Guttman, Kandan, Kandel (2006) indicate that managers try to realize forecasts even in the absence of the target bonus.

In addition, stock options, which is a mechanism used by shareholders in order to better align the interests of managers on the long-term value, may affect meeting analysts' forecasts. Indeed, Aboody and Kasznick (2000) confirm that the forecast bias is less positive in the month prior to options' offer; managers disclose bad information before the offer. Moreover, according to Bolliger and Kast (2007), options encourage managers to guide analysts' expectations downward since a low price corresponds to a relatively low exercise price. Bauman and Shaw (2006) illustrate that the propensity to meet analysts' forecasts is positively related to the use of options in top executives' compensation plans. Moreover, Kanagaretnam, Lobo and Mathiew (2012) find that forecast optimism increases as the proportion of CEO compensation from stock options increases. CEOs holding a great part of options take more risk and publish opportunistic disclosures which make the prediction task more complex, the optimistic bias is higher for these firms. They document a decrease in the quality of analysts' forecasts when the proportion of options increases.

$\mathrm{H}_{1.4}$ : Bonus and options increase the likelihood of meeting forecasts.

\subsection{The Control Committees}

Monitoring function, which is exercised through the board of directors, limits opportunistic behavior of those responsible for managing the firm who can expropriate wealth's shareholders. In the disciplinary context, the presence of effective monitoring committees is dedicated to the prevention of opportunistic managerial behavior. Shareholders control managers through committees grouped under the Board.

To our knowledge, no study examined the relationship between the activeness of control committees and the tendency of meeting analysts' forecasts. CEOs achieve analysts' forecasts are designed to increase share price, mainly to increase their compensation (it is then a question of the role of the compensation committee), they are supported by auditors (then it is question of the role of the audit committee); which can lead to overvalued 
securities and also damage the future of the company.

Board Directors represents the top of the control system in firms, bringing the dual roles of control and ratification, it plays an active role in the process of preparing financial reports. We assume that board effectiveness can constrain opportunistic managerial behavior. Xie, Davidson and DaDalt (2003) conclude that board activity may be an important factor in reducing the propensity of managers to engage in earnings management.

In addition, Board delegates responsibility for overseeing financial reporting to the audit committee which plays a critical role in controlling and monitoring the process of the development of accounting information. According to Abbott, Parker and Park (2000), firms with audit committees that met more than twice a year, have fewer problems in their financial reports, activity and independence of audit committee reduce likely aggressive financial statement. Xie et al. (2003) document that an active committee is more able to control directors. Various professional publications and reports suggest that the higher number of meetings of the audit committee is important for financial reporting but no study consider the relationship between this activeness and meeting analysts' forecasts. Recently, Rickling, Rama and Raghunandan, (2013) suggest that audit fees are lower for firms meet or beat analysts' forecasts.

Compensation committee tries to improve the incentive scheme of executive compensation. We note, however, that research concerned by its determinants and position, in relation to the governance system, are currently limited. The definition of compensation policies is an element key of managerial coaching latitudes. According to Matsunaga and Park (2001), the compensation committee may consider not achieve the benchmarks as a penalty because it is a poor signal performance. Exceed the benchmarks is a public signal that allows the committee to justify CEO compensation; managers involved in market value can reward directors for achieving benchmarks (Barth, Elliott \& Finn, 1999).

$\mathrm{H}_{1.5}$ : High activity of control committees decreases the likelihood of meeting forecasts.

\subsection{Consistently Meeting and Corporate Governance}

Many studies have interested on meeting analysts forecasts, some of them are focused on consistently meeting analysts' forecasts (Note 1) (Kasznick \& McNichols, 2002; Lopez \& Rees, 2002; Kross, Ro \& Suk, 2011). Reviewing emerging research about consistently meeting or beating expectations: CMBE (Note 2), we have to make three observations:

First, the majority of these studies focused on the effect of CMBE essentially on capital market i.e. on security price, valuation, earnings response coefficients and market premium. According to Kasznick and McNichols (2002), the market assigns a higher value to firms that meet expectations consistently; this premium is persistent and not reversed over three years. For Lopez and Rees (2002), the market recognizes historical patterns of surprises and adjusts for the systematic component of unexpected earnings; it rewards firms that consistently beat forecasts by attaching a higher multiple of the unsystematic portion of unexpected earnings. In general, firms characteristics studied are essentially earnings response coefficient and cost of capital, so few research were concerned by fundamental and characteristics of these firms.

Secondly, there are methodological differences between studies of CMBE firms. A number of them considered annual earnings, so surprise was calculated as the difference between annual actual and estimated earning, while others considered quarterly earnings. Furthermore, the definition of consistently meeting analysts is different from a study to another. Some of studies take into account the number of non negative surprises when others regroup firms into distinct categories according to the establishment of the strategy for achieving analysts' forecasts. Moreover, the number of non negative surprise is different from one study to another. In fact, given the lack of theory on a minimum MBE length necessary for a firm to be considered as CMBE one, classifications of studied firms are arbitrary. Kasznick and McNichols (2002) consider the prior three years, while Bartov el al. (2002) use eight and twelve and prior quarters; more generally, Kross et al. (2011), define the level of MBE consistency based on the number of consecutive preceding MBE quarters on a backward rolling horizon; they constructed groups based on this length ( 4,8 and 12 consecutive quarters). In the same way, Adut, Duru and Galpin (2011) define habitual beater if earnings surprises, for 4, 8 or at least 10 of 12 consecutive quarters, are non negative. Thirdly, meeting forecasts interested researchers, especially post accounting scandals; they tried to examine tools used by managers to achieve these benchmarks. Earnings management, earnings forecasts and managing real activities are widely considered and attract more and more attention.

Prior research suggested that CMBE firms have more underlying economic performance (Barton \& Simko, 2002); that was considered as the goal of good corporate governance by controlling managers and enhancing 
transparency. Moreover analysts' forecasts are affected by corporate governance, in this context, Bhat, Hope and Kang (2006) show that governance transparency is positively associated with analyst forecasts accuracy after controlling for financial transparency. We assume that, like meeting analysts' forecasts, consistently do it is associated with governance mechanisms. In this approach, Adut et al. (2011) illustrate that corporate governance attributes are related with the likelihood to consistently meet or beat earnings benchmarks. Differently to this study, we don't use a corporate governance index that summarizes governance attributes, we would like to point out which and how specific attributes affect CMBE.

$\mathrm{H}_{2}$ : Governance mechanisms' affect the likelihood to consistently meeting and beating analysts' forecasts.

\subsection{Opportunistic Attitude and Meeting Forecasts}

Research recognized that firms manage both their earnings and analysts' forecasts to achieve earnings benchmarks (Burgsthaler \& Eames, 2006; Bartov et al., 2002; Matsumoto, 2002). Accounting studies suggested that firms engage in earnings management to achieve earnings benchmarks (Burgsthaler \& Dichev, 1997, Degeorge, Patel \& Zeckhauser, 1999). We assume that firms meeting and beating analysts forecast are more engaging in earnings management than others.

For CMBE firms, Kross et al. (2012) provide evidence that they issue more frequent bad news management forecasts than the firm with no established string of MBE. Similar to these findings, Williams and Sun (2011) argue that habitual MBE firms may not have always achieved analysts' forecasts through true earnings but may have used strategies (earnings management, expectation management, or both) to do so in the pre regulation periods. So that, CMBE firms are able to maintain this tendency because of their underlying performance or opportunism. But, we note that earnings management is also difficult to maintain over long period (Barton \& Simko, 2002); and as the MBE sting lengthens it become more difficult to achieve an MBE by issuing bad news i.e. management forecasts (Kross et al., 2011). CMBE are less engaging in opportunistic actions and are associated to solid corporate governance. Adut et al. (2012) conclude that firms with better corporate governance mechanisms are less likely to achieve a record of CMBE through opportunistic earnings management.

$\mathrm{H}_{3}$ : Length of non negative surprises affect earnings management attitude which decrease in the presence of effective governance attribute.

\section{Empirical Design and Results}

\subsection{Data Sample}

We refer to a sample of 300 U.S. firms, from 1999 to 2006 . We exclude financial institutions and foreign firms. The non-availability of analysts' forecasts has greatly reduced our sample. To ensure that results are not driving by firms entering or leaving the sample across the time period, we performed our study using a constant set of firms. We use several sources of information to build our database by performing a manual collection from several websites and some databases. In fact, we collect estimated earnings from website First Call; accounting and governance data were extracted from the SEC website; prices were collected from Yahoo. Institutional investors ownership, beta and the timeliness of the company were collected from Value Line database.

\subsection{Methodology of Research}

A company that records null or positive surprise may not be incited to achieve forecast but simply its performance has exceeded expectations. At this stage, a problem arises: if we consider a short time horizon, the probability of classifying incorrectly the firm as motivated to achieve the forecast is high since the period-specific effects can cause positive surprises. If we consider a very long horizon, few firms will satisfy this criterion. In consequence, we take into account the two criteria together, we specify the companies that meet forecasts for a year and then we distinguish companies that consecutively forecasts over a longer period. Prior researchers examined only three year's horizon, we extend this literature by investigating four and five years. We refer to studies of CMBE firms indicating, however, some arbitrary choice was necessary.

Table 1. Variables definitions

\begin{tabular}{ll}
\hline MEET & Firms meeting or beating 4 quarterly consensus in the year \\
CMBE2 & Firms meeting or beating at least 6 consecutive quarterly consensus in two years \\
CMBE3 & Firms meeting or beating at least 9 consecutive quarterly consensus in three years \\
CMBE4 & Firms meeting or beating at least 12 consecutive quarterly consensus in four years \\
CMBE5 & Firms meeting or beating at least 15 consecutive quarterly consensus in five years
\end{tabular}


We propose to test the following equation to explain the tendency of meeting analysts' forecasts by governance mechanisms while controlling fundamental characteristics. We estimate the following logistic regression model:

$$
\begin{gathered}
P(\text { Meet }=1)=\alpha_{0}+\alpha_{1-4}(\text { capital structure })+ \\
+\alpha_{5-6}(\text { CEO incentive compensation })+\alpha_{7-9}(\text { committees activity })+ \\
\alpha_{10-13} \text { control variables }+\varepsilon .
\end{gathered}
$$

We control for size given that larger firms are more transparent, make more voluntary disclosure; have more analysts following (Das, Levine \& Sivarmakrihnan, 1998). We also consider performance; earnings estimates are more accurate for performing and profitable firms (Lopez \& Rees, 2002). We also control for long term growth (LTG), in fact, according to Matsumoto (2002), high growth firms have greater incentives to avoid negative surprises. Finally we control financial risk given that riskier firms are more incited to meet analysts' forecast (Mikhail, Walther \& Willis, 1999).

Subsequently, we examine the motivations and constraints to achieving long-term financial analysts' forecasts. The relationship is expressed in the following model.

$$
\begin{gathered}
\left.P(\text { CMBEX }=1)=\alpha_{0}+\alpha_{1^{-4}} \text { (Capital structure }\right)+\alpha_{5-6}(\text { CEO incentive compensation })+\alpha_{7-9} \text { (committees activity) } \\
+\alpha_{10-13}(\text { control variables })+\varepsilon . \quad(2 \leq \mathrm{X} \leq 5)
\end{gathered}
$$

To capture the influence of corporate attributes on earnings management to meet and beat analysts' forecasts, we add variables interaction between discretionary accruals and the governance attributes (Model 3).

$$
\begin{gathered}
P(M y)=\alpha_{0}+\alpha_{1-4}(\text { Capital structure })+\alpha_{5-6}(C E O \text { incentive compensation })+\alpha_{7-9}(\text { committees' activity })+\alpha_{7} \\
\text { Earnings Management }+\alpha_{8-16}(\text { Governance attributes } * \text { Earnings management })+\alpha_{17-22}(\text { control variables })+\varepsilon . \\
(1 \leq \mathrm{y} \leq 5) .
\end{gathered}
$$

Where My $(1 \leq y \leq 5)=1$ if the firm meet or beat consecutively 4, 6, 9, 12 and 15 previous quarterly earnings forecast.

\subsection{Descriptive Statistics}

First, we remark that $52.4 \%$ of companies are Meet i.e. more than half of the sample can meet or beat analysts' forecast for four quarters in the year. Secondly, for CMBE firms, we note that almost half of them are able to implement this strategy for the first two years, however, it seems that persistence is difficult to achieve since frequencies are decreasing, the differences between the frequencies are large. Annual frequency of CMBE firms

\begin{tabular}{|c|c|c|c|c|c|c|}
\hline Name & Description & Mean & Meet $=0$ & Meet=1 & Difference & Signif \\
\hline Inst.own & $\begin{array}{l}\text { Securities held by Institutional investors /total } \\
\text { securities }\end{array}$ & 0.6857 & 0.6798 & 0.6886 & -0.0088 & -1.1954 \\
\hline Block.inst & $\begin{array}{l}\text { Securities held by Institutional investors } \\
\text { having }>5 \% \text { / total securities }\end{array}$ & 0.1509 & 0.1567 & 0.1447 & 0.012 & $2.0338 * *$ \\
\hline $\begin{array}{l}\text { Small.inst } \\
\text { (Note } 3)\end{array}$ & $\begin{array}{l}\text { Smaller Institutional investors securities / total } \\
\text { securities }\end{array}$ & 0.5348 & 0.5230 & 0.5434 & -0.0204 & $-3.0627 * * *$ \\
\hline Ceo. Own & CEO securities / total securities & 0.0244 & 0.0252 & 0.0236 & 0.0016 & 0.6417 \\
\hline Deb & Total debt/Total assets & 0.2716 & 0.2868 & 0.2581 & 0.0277 & $1.5891 * *$ \\
\hline Inc & Option +Bonus/ Total Compensation (Note4) & 0.5776 & 0.5532 & 0.6153 & -0.0620 & $-5.1287 * * *$ \\
\hline Bonus & Bonus/ Total compensation & 0.1846 & 0.1681 & 0.1991 & -0.0314 & $-4.0533 * * *$ \\
\hline Options & Options/Total compensation & 0.3930 & 0.3834 & 0.4131 & -0.0297 & $-2.1330 * *$ \\
\hline M.B & Number of board meetings & 7.6711 & 7.8864 & 7.4752 & 0.4112 & $2.8012 * *$ \\
\hline
\end{tabular}
is decreasing over time, companies increasingly difficult to maintain this strategy (Table 2).

Table 2. Descriptive statistics of dependent variables

\begin{tabular}{llllll}
\hline & MEET & CMBE2 & CMBE3 & CMBE4 & CMBE5 \\
\hline 1 & $52.4 \%$ & $49.0 \%$ & $35.43 \%$ & $31.13 \%$ & $24.95 \%$ \\
0 & $47.6 \%$ & $51.0 \%$ & $64.57 \%$ & $68.87 \%$ & $75.05 \%$ \\
\hline
\end{tabular}

\subsection{Empirical Results of Meeting and Corporate Governance Mechanisms}

We begin our empirical research by defining variables and presenting descriptive statistics.

Table 3. Statistics of explicative variables 


\begin{tabular}{llllll}
\hline M.AC & Number of audit committee meetings & 6.3526 & 6.6613 & 6.0716 & 0.5899 \\
M.CC & Number of compensation committee meetings & 4.9139 & 4.9316 & 4.897 & 0.0338 \\
Size & Logarithm of total capitalization & 21.936 & 21.766 & 22.091 & -0.0263 \\
Performance & Return on Assets & 0.0487 & 0.0348 & 0.0612 & 0.3512 \\
LTG & Rank of a stock's relative market performance & 3.0292 & 3.2131 & 2.8620 & 0.3512 \\
& in the year ahead. (Note 5) & & & $8.6093 * * *$ \\
Risk & Beta & 1.0386 & 1.0409 & 1.0360 & 0.0046 \\
\hline
\end{tabular}

$* \operatorname{sig}$ at $10 \%, * * \operatorname{sig}$ at $5 \%, * * * \operatorname{sig}$ at $1 \%$.

The mean of small institutional, incentive CEO compensation is significantly higher for meet firms than for non-meet firms. Moreover, meet firms are larger, enjoy better performance and have more long term prospect growth.

To test our first hypothesis, we estimate model (1) in two forms, the first take institutional investors and incentive compensation, the second separate them in their two components.

$$
\begin{gathered}
P(\text { Meet }=1)=\alpha_{0}+\alpha_{1} \text { Inst.own }+\alpha_{2} \text { Ceo.own }+\alpha_{3} \text { Deb }+\alpha_{4} \text { inc }+\alpha_{5} \text { M.B }+\alpha_{6} \text { M.AC }+\alpha_{7} \text { M.CC }+ \text { Control } \\
\text { Variables }+(\text { Year and Firm specifications })+e
\end{gathered} \begin{array}{r}
\text { (1a) } \\
P(\text { Meet }=1)=\alpha_{0}+\alpha_{1} \text { Block.inst }+\alpha_{2} \text { Small.inst }+\alpha_{3} \text { Ceo.own }+\alpha_{4} \text { Deb }+\alpha_{5} \text { Bonus }+\alpha_{6} \text { Option }+ \text { M.B }+\alpha_{8} \\
\text { M.AC }+\alpha_{9} \text { M.CC }+ \text { Control variables }+(\text { Year and Firm specifications })+e
\end{array}
$$

Estimation results, presented in the Table 4 indicate that institutional investors have significant effect on the probability to meet analysts' forecasts (Model 1-a) but interestingly institutional investors that hold more than $5 \%$ have positive but not significant effect, their contribution to this trend is limited contrarily to those who hold less than 5\%, they have a positive and significant effect. Meet firms attract more institutional investors with low ownership, "smaller" institutional investors, than big ones. This confirms $\mathrm{H}_{1.1}$ and adds to previous literature concerning the relationship between importance of institutional ownership on meeting and beating analysts' forecasts.

Table 4. Meeting and governance attributes

\begin{tabular}{llllll}
\hline & \multicolumn{3}{c}{ Model 1a } & \multicolumn{2}{c}{ Model 1b } \\
\cline { 2 - 5 } & coefficients & $(\mathrm{p})$ & Coefficients & $(\mathrm{p})$ & \\
\hline Inst.own & $0.7559^{* *}$ & $(0.028)$ & - & $\mathrm{H}_{1.1}$ \\
Block.Inst & - & & 0.5140 & $(0.260)$ & \\
Small.Inst & - & & $0.8789 * *$ & $(0.026)$ & \\
Ceo.own & -0.4071 & $(0.679)$ & -0.4774 & $(0.622)$ & $\mathrm{H}_{1.2}$ \\
Deb & $-0.4390^{* *}$ & $(0.037)$ & -0.4376 & $(0.038)$ & $\mathrm{H}_{1.3}$ \\
Inc & $0.4396^{* *}$ & $(0.030)$ & - & - & $\mathrm{H}_{1.4}$ \\
Bonus & - & - & $1.3004 * * *$ & $(0.000)$ & \\
Options & - & - & $0.3760^{*}$ & $(0.061)$ & \\
M.B & $-0.0416^{* *}$ & $(0.021)$ & $-0.0394 * *$ & $(0.028)$ & $\mathrm{H}_{1.5}$ \\
M.AC & -0.0017 & $(0.930)$ & -0.0019 & $(0.921)$ & \\
M.CC & 0.2057 & $(0.381)$ & 0.0181 & $(0.432)$ & \\
Performance & $1.6804^{* * *}$ & $(0.002)$ & $1.5164 * * *$ & $(0.005)$ & \\
Size & $0.1156^{* * *}$ & $(0.001)$ & $0.1153^{* * *}$ & $(0.002)$ & \\
LTG & $-0.4274 * * *$ & $(0.000)$ & $-0.3975^{* * *}$ & $(0.000)$ & \\
Risk & 0.0627 & $(0.735)$ & 0.1353 & $(0.468)$ & \\
Pseudo R ${ }^{2}$ & $6.60 \%$ & & $6.96 \%$ & & \\
\hline
\end{tabular}

Moreover, we demonstrate than the ownership of CEO have negative but not significant effect on this tendency, CEO doesn't invest in meet firms; this confirms the result of Mande and Soon (2012); in fact, after controlling CEO centrality, ownership of CEO have doesn't have significantly effect on meeting and beating.

In addition, we note that the company is more leveraged, the less it is trying to achieve analysts' forecasts. Debt is a constraint to the achievement of forecasts; creditors may constitute a control mechanism that prevents leaders in monitoring the implementation of analysts' forecasts. 
Concerning incentive compensation, it affect significantly and positively meeting analysts forecasts (1a), both bonus and stock options have positive and significant effect (Model 1b). These results confirm our hypothesis $\left(\mathrm{H}_{1.4}\right)$ and prior documented relationship, the CEO of firms that meet and beat analysts' forecasts are more compensated with bonus and options than others CEOs. Finally, only the activity of the board control meeting tendency, firms that meet analysts' forecasts have fewer board meetings than firms that do not.

\subsection{Empirical Results of Consistently Meeting Expectations and Corporate Governance}

To investigate the role of corporate governance mechanisms for CMBE, we estimate the Model (2) for four different horizons (Table 5).

Table 5. CMBE and governance attributes

\begin{tabular}{lllllllll}
\hline Variables & CMBE2 & $\mathrm{P}$ & $\mathrm{CMBE} 3$ & $\mathrm{p}$ & $\mathrm{CMBE} 4$ & $\mathrm{P}$ & $\mathrm{CMBE} 5$ & $\mathrm{P}$ \\
\hline Block.Inst & 1.1925 & $(0.016)$ & 1.5529 & $(0.008)$ & 1.3216 & $(0.059)$ & 1.0075 & $(0.273)$ \\
Small.inst & 1.0961 & $(0.014)$ & 1.1465 & $(0.030)$ & 1.1010 & $(0.085)$ & 1.8971 & $(0.029)$ \\
Ceo.own & 0.7051 & $(0.512)$ & 2.1165 & $(0.085)$ & 2.3744 & $(0.113)$ & 3.2501 & $(0.096)$ \\
Deb & -0.4436 & $(0.001)$ & -0.1968 & $(0.424)$ & -0.4416 & $(0.217)$ & -0.2704 & $(0.572)$ \\
Bonus & 1.3009 & $(0.001)$ & 0.7845 & $(0.081)$ & 0.9472 & $(0.074)$ & 0.9903 & $(0.163)$ \\
Option & 0.4455 & $(0.045)$ & 0.4387 & $(0.090)$ & 0.7301 & $(0.021)$ & 1.1909 & $(0.006)$ \\
M.B & -0.0459 & $(0.020)$ & -0.0296 & $(0.195)$ & -0.0391 & $(0.181)$ & -0.0617 & $(0.117)$ \\
M.AC & -0.0088 & $(0.663)$ & -0.0248 & $(0.268)$ & -0.0326 & $(0.204)$ & -0.0094 & $(0.758)$ \\
M.CC & 0.0175 & $(0.492)$ & 0.0287 & $(0.339)$ & 0.0265 & $(0.459)$ & 0.0617 & $(0.177)$ \\
Pseudo $\mathrm{R}^{2}$ & $6.92 \%$ & & $5.56 \%$ & & $6.51 \%$ & & $5.15 \%$ & \\
\hline
\end{tabular}

First, we particularly note that the two types of institutional investors have a positive and significant effect on CMBE, that wasn't the case for meet firms. Big institutional investors are also interested in this type of firms, meeting analysts' forecasts over six quarters in the last two years is a good signal for this investors, which is stronger than meeting on one year. Particularly, CMBE firms have larger CEO ownership than non CMBE; difference between groups is significant over the horizon of three years. From three year horizon, debt and board activeness lose their significantly negative power on the CMBE firms. Finally, incentive compensation (both bonus and option) still have positive effect on CMBE.

Governance attributes' of meet firms don't differ significantly from those of CMBE2. But over three years the CMBE become more affected by big institutional ownership and CEO ownership. Like to Adut et al. (2011), we conclude that some governance mechanisms are associated with CMBE, but we add that these mechanisms are also associated to this tendency over three year's horizon (four and five years).

\subsection{Meeting, Corporate Governance and Earnings Management}

Inspiring by Barua et al. (2006), we estimate abnormal accruals, a proxy for opportunistic earnings management, by using the following variation of the Modified Jones Model developed by Dechow et al. (1995).

Where:

$$
\frac{T A_{i t}}{A_{i, t-1}}=k_{1 t} \frac{1}{A_{i, t-1}}+k_{2} \frac{(\Delta R E V i t-\Delta R E C \text { it })}{\text { Assets }_{i, t-1}}+k_{3} \frac{P P E_{i t}}{\text { Assets }_{i, t-1}}+k 4 \Delta C F O i t+\varepsilon_{i t}
$$

$\mathrm{TA}_{\mathrm{it}}:$ Total accruals $=$ Income before taxes- Operating Cash Flow for the firm $\mathrm{i}$ for the year $\mathrm{t}$.

$\mathrm{A}_{\mathrm{it}-1}$ : Total assets for year $\mathrm{t}-1$.

$\triangle \mathrm{REV}_{\mathrm{it}}$ : Revenues of firm i for year $\mathrm{t}$ less revenues for year $\mathrm{t}-1$ scaled by total assets for $\mathrm{t}-1$

$\triangle \mathrm{REC}_{\mathrm{it}}$ : Receivables of firm i for year $\mathrm{t}$ less receivables for $\mathrm{t}-1$ scaled by total assets for $\mathrm{t}-1$

$\triangle \mathrm{CFO}$ : Operating Cash flow for firm i for year $\mathrm{t}$ less operating cash flow for $\mathrm{t}-1$ scaled by total assets for $\mathrm{t}-1$.

PPE: Gross property plant and equipment for firm i for year $t$ scaled by total assets for $t-1$.

We calculate $\mathrm{DAC}=\mathrm{TA}$ - Estimated TA.

Empirical results (Table 6) show that DAC are positive but not significantly different from zero, this result indicate that opportunistic management is not evident for these firms. Condemning all firms that meet analysts' forecasts by opportunistic behavior is rejected; some firms can meet analysts' forecasts without earnings 
management.

Moreover, consistent with preceding results, more institutional investors ownership and incentive compensation are associated with meeting analysts forecasts. More interestingly, we note that block institutional ownership play an important role in reducing earnings management associated with meeting analysts forecasts. Nevertheless, stock options aggravate the earnings management problem. Specially, we note that incentive compensation doesn't act in the same way, while options enhance discretionary accruals, bonus doesn't do it. There is a difference between the two components of incentive compensation relative to opportunistic behavior. In sum, empirical findings support our hypothesis that meeting analysts' forecasts is associated with governance mechanisms and some of them reduce the earnings management. To further investigate this relationship, we next, test this hypothesis for CMBE firms.

Table 6. Earnings management, meeting and corporate governance

\begin{tabular}{|c|c|c|c|c|c|}
\hline Variables & $\begin{array}{l}\text { Meet } \\
\text { (p) }\end{array}$ & $\begin{array}{l}\text { M2 } \\
\text { (p) }\end{array}$ & $\begin{array}{l}\text { M3 } \\
\text { (p) }\end{array}$ & $\begin{array}{l}\text { M4 } \\
\text { (p) }\end{array}$ & $\begin{array}{l}\text { M5 } \\
\text { (p) }\end{array}$ \\
\hline Block.Inst & $\begin{array}{l}0.6836 \\
(0.129)\end{array}$ & $\begin{array}{l}1.0911^{* *} \\
(0.037)\end{array}$ & $\begin{array}{l}1.2556^{*} \\
(0.053)\end{array}$ & $\begin{array}{l}1.2256 \\
(0.137)\end{array}$ & $\begin{array}{l}1.1654 \\
(0.303)\end{array}$ \\
\hline Small.inst & $\begin{array}{l}0.8091 * * \\
(0.038)\end{array}$ & $\begin{array}{l}0.9033 * * \\
(0.048)\end{array}$ & $\begin{array}{l}1.1934 * * \\
(0.038)\end{array}$ & $\begin{array}{l}1.4054 * \\
(0.062)\end{array}$ & $\begin{array}{l}1.4403 \\
(0.178)\end{array}$ \\
\hline Ceo.own & $\begin{array}{l}-0.7866 \\
(0.422)\end{array}$ & $\begin{array}{l}0.3000 \\
0.787\end{array}$ & $\begin{array}{l}0.8589 \\
0.524\end{array}$ & $\begin{array}{l}-0.1434 \\
0.938\end{array}$ & $\begin{array}{l}-1.6007 \\
0.606\end{array}$ \\
\hline Deb & $\begin{array}{l}-0.4003 * \\
(0.074)\end{array}$ & $\begin{array}{l}-0.5188^{* *} \\
0.043\end{array}$ & $\begin{array}{l}-0.4573 \\
0.124\end{array}$ & $\begin{array}{l}-0.6007 \\
0.163\end{array}$ & $\begin{array}{l}-0.4471 \\
0.470\end{array}$ \\
\hline Bonus & $\begin{array}{l}1.3337 * * * \\
0.000\end{array}$ & $\begin{array}{l}1.7295 * * * \\
0.000\end{array}$ & $\begin{array}{l}1.5945^{* * *} \\
0.001\end{array}$ & $\begin{array}{l}1.7575 \\
0.004\end{array}$ & $\begin{array}{l}2.0429 \\
0.021\end{array}$ \\
\hline Option & $\begin{array}{l}0.3905^{* *} \\
0.053\end{array}$ & $\begin{array}{l}0.6113^{* * *} \\
0.009\end{array}$ & $\begin{array}{l}0.7585^{* * *} \\
0.009\end{array}$ & $\begin{array}{l}0.9678^{* *} \\
0.010\end{array}$ & $\begin{array}{l}1.3673 \\
0.013\end{array}$ \\
\hline M.B & $\begin{array}{l}-0.0404 * * \\
0.022\end{array}$ & $\begin{array}{l}-0.0646^{* * *} \\
0.003\end{array}$ & $\begin{array}{l}-0.0458 * \\
0.082\end{array}$ & $\begin{array}{l}-0.0310 \\
0.0355\end{array}$ & $\begin{array}{l}-0.0491 \\
0.0317\end{array}$ \\
\hline M.AC & $\begin{array}{l}0.0025 \\
0.698\end{array}$ & $\begin{array}{l}0.0044 \\
0.853\end{array}$ & $\begin{array}{l}-0.0171 \\
0.492\end{array}$ & $\begin{array}{l}-0.0347 \\
0.245\end{array}$ & $\begin{array}{l}-0.0537 \\
0.167\end{array}$ \\
\hline M.CC & $\begin{array}{l}0.0185 \\
0.419\end{array}$ & $\begin{array}{l}0.0298 \\
0.0261\end{array}$ & $\begin{array}{l}0.0577^{*} \\
0.079\end{array}$ & $\begin{array}{l}0.0637 \\
0.0119\end{array}$ & $\begin{array}{l}0.0944 \\
0.094\end{array}$ \\
\hline DAC & $\begin{array}{l}0.3222 \\
0.536\end{array}$ & $\begin{array}{l}0.6010 \\
0.408\end{array}$ & $\begin{array}{l}2.3719^{* * *} \\
0.058\end{array}$ & $\begin{array}{l}2.7453^{*} \\
0.064\end{array}$ & $\begin{array}{l}2.3458 \\
0.381\end{array}$ \\
\hline DAC*Block.Inst & $\begin{array}{l}-1.3640^{*} \\
0.061\end{array}$ & $\begin{array}{l}-2.2879 * * \\
0.014\end{array}$ & $\begin{array}{l}-4.2167 * * * \\
0.004\end{array}$ & $\begin{array}{l}-3.9218 \\
0.006\end{array}$ & $\begin{array}{l}-2.3873 \\
0.381\end{array}$ \\
\hline *Small.inst & $\begin{array}{l}-0.7098 \\
0.915\end{array}$ & $\begin{array}{l}-0.4152 \\
0.646\end{array}$ & $\begin{array}{l}-2.3073 * \\
0.094\end{array}$ & $\begin{array}{l}-3.4602 * \\
0.074\end{array}$ & $\begin{array}{l}-4.9063 \\
0.397\end{array}$ \\
\hline * Ceo.own & $\begin{array}{l}-0.2255 \\
0.555\end{array}$ & $\begin{array}{l}-2.1836 \\
0.385\end{array}$ & $\begin{array}{l}-0.2244 \\
0.957\end{array}$ & $\begin{array}{l}4.3871 \\
0.599\end{array}$ & $\begin{array}{l}2.3374 \\
0.791\end{array}$ \\
\hline *Deb & $\begin{array}{l}0.0523 \\
0.905\end{array}$ & $\begin{array}{l}0.0433 \\
0.661\end{array}$ & $\begin{array}{l}0.1222 \\
0.272\end{array}$ & $\begin{array}{l}0.1558 \\
0.366\end{array}$ & $\begin{array}{l}0.3029 \\
0.450\end{array}$ \\
\hline *Bonus & $\begin{array}{l}0.0618 \\
0.905\end{array}$ & $\begin{array}{l}-0.7957 \\
0.281\end{array}$ & $\begin{array}{l}-1.5562 \\
0.220\end{array}$ & $\begin{array}{l}-1.6512 \\
0.342\end{array}$ & $\begin{array}{l}-3.8942 \\
0.270\end{array}$ \\
\hline *Option & $\begin{array}{l}0.5728^{*} \\
0.093\end{array}$ & $\begin{array}{l}0.9124 * \\
0.096\end{array}$ & $\begin{array}{l}0.8907^{*} \\
0.098\end{array}$ & $\begin{array}{l}0.9362 \\
0.377\end{array}$ & $\begin{array}{l}2.1328 \\
0.195\end{array}$ \\
\hline * M.B & $\begin{array}{l}-0.0041 \\
0.931\end{array}$ & $\begin{array}{l}-0.0143 \\
0.812\end{array}$ & $\begin{array}{l}-0.1348^{*} \\
0.099\end{array}$ & $\begin{array}{l}-0.1760 \\
0.132\end{array}$ & $\begin{array}{l}-0.3342 \\
0.083\end{array}$ \\
\hline * M.AC & $\begin{array}{l}-0.0095 \\
0.679\end{array}$ & $\begin{array}{l}0.0371 \\
0.231\end{array}$ & $\begin{array}{l}0.0661 \\
0.123\end{array}$ & $\begin{array}{l}0.0631 \\
0.342\end{array}$ & $\begin{array}{l}0.1740 \\
0.133\end{array}$ \\
\hline * M.CC & $\begin{array}{l}0.0365 \\
0.453\end{array}$ & $\begin{array}{l}-0.0019 \\
0.970\end{array}$ & $\begin{array}{l}0.0829 \\
0.287\end{array}$ & $\begin{array}{l}0.1808^{*} \\
0.091\end{array}$ & $\begin{array}{l}0.3677 \\
0.027\end{array}$ \\
\hline Pseudo $\mathrm{R}^{2}$ & $7.34 \%$ & $8.79 \%$ & $8.25 \%$ & $7.77 \%$ & $8.55 \%$ \\
\hline
\end{tabular}


We note that firms that are engaging in significant earnings management are firms consistently achieved previously earnings management for more than five or eight quarters. They use discretionary accruals to continue meeting and beating quarterly analysts' forecasts for the next year. After a considerable number of non negative surprises, CEO take more risk to avoid breaking the consistency. This attitude is temperate by institutional investors (both block and transient) and board activeness but is enhanced by stock options. Note that activity of compensation committee can encourage to earnings management for consecutively meeting analysts' forecasts. This risky attitude change for five years horizon, discretionary accruals are not significant and institutional investors are not efficient. This case can be attributable to change in financial American environment after SOX, since the test for this category of firms includes only the period after SOX. For this reason we will verify the effect of the scandals and SOX periods on our empirical results.

\section{Additional Tests}

\subsection{The Effect of Governance Crisis in Meeting Tendency}

Financial or accounting crisis of 2001-2002 was attributed to the failure of governance. During it, sell-side analysts compromised their objectivity and independence in order to win investment-banking business and to maintain their access to senior management. They were seriously criticized, this lead them to be more conservative about their previsions and more vigilant about disclosures.

The SEC has responded to scandals by adopting the Sarbanes-Oxley Act (SOX) that have resulted in a significant restructuring of corporate governance rules. Analysts are submitted to new regulations (Note 6) that sought to eliminate interactions and flows of information to prevent activities giving analysts incentives to bias their research. Adopting better corporate governance practices is expected to improve the monitoring of management and reduces information asymmetry problems. SOX affected positively corporate disclosure quality (Arping \& Sautner, 2013), decreased earnings management (Cohen, Dey \& Lys, 2008); enhanced the monitoring role of the board (Cohen, Krisnamoorthy \& Wright, 2010). In addition, market become more skeptical for firms that meet or beat expectation after scandals, the premium assigned to meet and smaller beater firms has disappeared in the post-scandals period while the premium assigned to big beaters has diminished. (Koh et al. 2008). We attend that governance mechanisms will be more effective in controlling firms, and so in the meeting tendency in post SOX period (Results are summarized on Table 7)

Table 7. Crisis, meeting and corporate governance

\begin{tabular}{lllll}
\hline & \multicolumn{2}{c}{ Before Crisis } & \multicolumn{2}{c}{ After crisis } \\
\hline Block.Inst & Coefficient & $\mathrm{P}$ & Coefficients & $\mathrm{P}$ \\
Trans.own & 0.2134 & $(0.799)$ & 1.6944 & $(0.042)$ \\
Ceo.own & 0.8084 & $(0.238)$ & 1.3791 & $(0.073)$ \\
Debt & -0.7615 & $(0.655)$ & -0.6411 & $(0.745)$ \\
Bonus & -0.1852 & $(0.355)$ & -0.8213 & $(0.083)$ \\
Options & 0.6763 & $(0.290)$ & 2.1516 & $(0.001)$ \\
M.B & 0.0834 & $(0.814)$ & 0.6567 & $(0.100)$ \\
M.AC & -0.0095 & $(0.766)$ & -0.0826 & $(0.022)$ \\
M.CC & 0.0376 & $(0.710)$ & -0.0119 & $(0.672)$ \\
DAC & -0.057 & $(0.157)$ & 0.0722 & $(0.090)$ \\
DAC*Blok & 0.1714 & $(0.855)$ & -0.9003 & $(0.097)$ \\
* Small & -0.3481 & $(0.854)$ & -4.7203 & $(0.027)$ \\
* Ceo & -0.8772 & $(0.446)$ & -4.8760 & $(0.020)$ \\
* Deb & 1.2121 & $(0.786)$ & -12.1459 & $(0.143)$ \\
* Bonus & -0.1891 & $(0.626)$ & 0.1076 & $(0.540)$ \\
* Option & -0.0313 & $(0.980)$ & -1.8333 & $(0.335)$ \\
* M.B & 0.2435 & $(0699)$ & 1.9838 & $(0.093)$ \\
* M.AC & 0.0594 & $(0.520)$ & -0.0981 & $(0.422)$ \\
* M.CC & 0.0589 & $(0.589)$ & -0.0530 & $(0.550)$ \\
Pseudo R ${ }^{2}$ & 0.0142 & $(0.886)$ & 0.1269 & $(0.288)$ \\
\hline & $5.62 \%$ & & $10.27 \%$ & \\
\hline
\end{tabular}


In fact, just before crisis (1999-2000), all mechanisms are completely inefficient. Firms that meet analysts' forecasts don't have specific governance mechanisms. After crisis (2003-2004), the number of meetings of board affects negatively the tendency of analysts' forecasts meeting. Moreover, creditors and all institutional investors control meeting forecast. Incentive compensation and activeness compensation committees have a positive effect. After SOX, the coefficient of earnings management is strongly negative; this implies that firms meeting forecasts don't use discretionary accrual to achieve benchmarks. Institutional investors, both big and smaller ones, control massively this tendency. However, we note that manager, who have relatively more options, is more likely to meet forecasts through discretionary accruals, this confirms the effect of incentive compensation, in particular options, on managerial decisions.

\subsection{Sensitivity Tests}

As we signal in our methodology section, the definition of meeting incorporates some arbitrary choice. To confirm that our results are not affected by our initial choice of the dependant variable, we construct other variables to detect meeting and CMBE named NM X: the number of maximum consecutive quarters with no negative surprise during $X$ years $(1 \leq X \leq 5)$, taking into account imperatively meeting four quarters of the current year. We estimate previous models with new dependant variables using Ordered Logit Estimation (Table 8).

Table 8. Number of consecutive positive surprises, earnings management and governance

\begin{tabular}{lllllllllll}
\hline Variables & NCM1 & $\mathrm{P}$ & $\mathrm{NCM} 2$ & $\mathrm{P}$ & $\mathrm{NCM}$ & $\mathrm{P}$ & $\mathrm{NCM} 4$ & $\mathrm{P}$ & $\mathrm{NCM} 5$ & $\mathrm{P}$ \\
\hline Block.Inst & 0.6989 & $(0.087)$ & 1.1047 & 0.019 & 1.0142 & 0.052 & 0.9221 & 0.125 & 1.6105 & 0.037 \\
Small.Inst & 1.006 & $(0.005)$ & 1.0053 & 0.015 & 0.9341 & 0.046 & 1.0311 & 0.062 & 1.4320 & 0.052 \\
Ceo.own & -0.6991 & $(0.432)$ & 0.1908 & 0.853 & -0.2039 & 0.862 & -0.6428 & 0.649 & -0.5455 & 0.763 \\
Deb & -0.1346 & $(0.259)$ & -0.4545 & 0.054 & -0.5459 & 0.039 & -0.6970 & 0.033 & -0.7953 & 0.070 \\
Bonus & 1.4107 & $(0.000)$ & 1.6000 & 0.000 & 1.6800 & 0.000 & 1.7985 & 0.000 & 1.9645 & 0.001 \\
Option & 0.4603 & $(0.010)$ & 0.4798 & 0.023 & 0.6316 & 0.008 & 1.0285 & 0.000 & 0.9038 & 0.014 \\
M.B & -0.5306 & $(0.001)$ & -0.0506 & 0.008 & -0.0502 & 0.017 & -0.0417 & 0.094 & -0.0811 & 0.016 \\
M.AC & 0.0110 & $(0.518)$ & -0.0036 & 0.848 & -0.0058 & 0.770 & -0.0256 & 0.232 & -0.0191 & 0.468 \\
M.CC & 0.0153 & $(0.467)$ & 0.0344 & 0.148 & 0.0493 & 0.070 & 0.0595 & 0.053 & 0.0754 & 0.051 \\
DAC & 0.1904 & $(0.678)$ & 0.4293 & 0.458 & 0.9927 & 0.173 & 1.6578 & 0.083 & 2.9356 & 0.026 \\
DAC*Block.I & -1.0670 & $(0.088)$ & -1.8958 & 0.018 & -2.7583 & 0.009 & -2.0009 & 0.098 & -4.6358 & 0.014 \\
Small.inst & -0.5304 & $(0.374)$ & -0.3914 & 0.609 & -1.1577 & 0.233 & -1.9275 & 0.092 & -4.6414 & 0.012 \\
Ceo.own & -0.7689 & $(0.667)$ & -1.3983 & 0.536 & -1.9020 & 0.462 & -0.9882 & 0.749 & -3.3379 & 0.394 \\
Deb & 0.0001 & $(0.998)$ & 0.0462 & 0.620 & 0.0854 & 0.358 & 0.0535 & 0.734 & 0.1419 & 0.504 \\
Bonus & 0.1033 & $(0.819)$ & -0.1464 & 0.773 & 0.1065 & 0.876 & -0.1557 & 0.833 & -1.3019 & 0.397 \\
Option & 0.4747 & $(0.108)$ & 1.0080 & 0.008 & 1.1431 & 0.016 & 0.8291 & 0.168 & 1.6785 & 0.116 \\
Rca & 0.0099 & $(0.804)$ & -0.0557 & 0.272 & -0.1085 & 0.087 & -0.1781 & 0.040 & -0.1444 & 0.208 \\
Rcau & -0.0023 & $(0.911)$ & 0.0129 & 0.610 & 0.0241 & 0.413 & 0.0126 & 0.760 & 0.0882 & 0.199 \\
Rcomp & 0.0217 & $(0.586)$ & 0.0387 & 0.391 & 0.0917 & 0.116 & 0.09449 & 0.186 & 0.1802 & 0.098 \\
Pseudo R & $5.98 \%$ & & $5.06 \%$ & & $4.13 \%$ & & $3.33 \%$ & & $3.03 \%$ & \\
\hline & & & & & & & & &
\end{tabular}

Results are similar than earlier, this confirms our suggestions that governance attributes affect both meeting and consistently meeting and beating forecasts.

We note that when we take into consideration the exact number of meeting, options affect meeting through enhancing earnings management for two and three years the same constraining effect is observed for institutional investors

\section{Conclusion}

The mainstream of research, interested on analysts' forecasts focuses on the consequences of meeting expectation, little attention has been paid to specific characteristics of these firms and especially their governance attributes. This paper extends this area of research by identifying shared characteristics of firms that have achieved quarterly analysts' consensus in the short and the long run time.

We documented that meeting firms have more institutional ownership especially small investors ones; their CEOs have more incentive compensation than others. Moreover, debt and board activity constrain meeting and beating expectations. Identifying firms that CMBE, we find that, over three year's horizon, the CEO ownership is more important for these firms. We note that incentive compensation and institutional ownership (both block 
and transient) are higher for CMBE firms. These results suggest that governance attributes are related with meeting and CMBE firms.

Exploring the opportunistic attitude, we examine the role of governance mechanisms in reducing earnings management related to meet or beat expectations. We find that increased institutional ownership reduce earnings management contrarily to granted options that exacerbate the opportunistic position. In addition, firms having achieved a string of meeting or beating analysts' consensus expectations manage earnings in order to maintain it, this attitude is only controlled by block institutional investors and encouraged by options whose positive effect remain over three years.

We also find that just before financial crisis, governance attributes are inefficient in controlling this tendency; the affect of these mechanisms is greater in the post-SOX period suggesting that this regulation and the market skepticism allowed more efficiency for corporate governance.

Our findings serve to regulators by discussing the effect of some rules on meeting and beating analysts' forecasts, further research in this area can test directly the effect of rules on managerial decisions. Empirical results of this study raise issues for future research. In fact, it remain unclear how firms succeed in the number game and how various methods of earnings real activities and forecasts management are used over time to avoid breaking consistency.

This study have certain limits, it review meeting tendency and not separate just meeting and beating firms that may be have different objectives and tools to meet analysts' forecasts and more interestingly have different investors' reaction both before and after financial crisis.

\section{References}

Abbott, L. J., Parker, S., \& Park, G. E. (2000). The effect of Audit Committee Activity and Independence on Corporate Fraud. Managerial Finance, 26(11), 55-68. http//dx.doi.org/ 10.1108/03074350010766990

Aboody, D., \& Kasznick, R. (2000). CEO Stock Option Awards and the Timing of Corporate Voluntary Disclosure. Journal of Accounting and Economics, 29(1), 73-100. http//dx.doi.org/10.1016/SO165-410(00)00014-8.

Adut, D., Duru, A., \& Galpin, W. L. (2011). The Role of Corporate Governance in Meeting or Beating Analysts' Forecast. Journal of Accounting Public Policy, 30, 188-198. http://dx.doi.org/10.1016/j.jaccpubpol.2011.02.002

Arping, S., \& Sautner, D. (2013). Did SOX Section 404 Make Firms Less Opaque? Evidence from Cross Listed Firms. Contemporary Accounting Research, 30(3), 1133-1165. http//dx.doi.org/10.1111/j.1911-3846.2012.01188.x

Baik, B., Kang, J. K., \& Morton, R. (2010). Why Are Analysts Less Likely to Follow Firms With High Managerial Ownership. Journal of Accounting, Auditing and Finance, 25(2), 171-200. http//dx.doi.org/10.1177/0148558X1002500202

Barth, M., Elliott, J., \& Finn, M. (1999). Market Rewards Associated With Patterns of Increasing Earnings, Journal of Accounting Research, 37(2), 387-413. http://dx.doi.org/10.2307/2491414

Barton, J., \& Simko, P. (2002). The Balance Sheet as Earnings Management Constraint. The Accounting Review, 77, 1-27. http://dx.doi.org/10.2308/accr.2002.77.s-1.1

Bartov, M., Givoly, D., \& Hayn, C. (2002). The Rewards to Meeting or Beating Earnings Expectations. Journal of Accounting and Economics, 33(2), 173-204. http://dx.doi.org/10.1016/S0165-4101(02)00045-9

Barua, A., Legoria, J., \& Moffitt, J. S. (2006). Accruals Management to Achieve Earnings Benchmarks: A Comparison of Pre-managed Profit and Loss Firms. Journal of Business Finance \& Accounting. 33(5-6), 653-670. http://dx.doi.org/10.1111/j.1468-5957.2006.00017.x

Bauman, M. P., \& Shaw, K. W. (2006). Stock Option Compensation and the Likelihood of Meeting Analysts' Quarterly Targets. Review of Quantitative Finance and Accounting, 26(3), 301-319. http://dx.doi.org/10.1007/s11156-006-7435-1

Bhat, G., Hope, O. K., \& Kang, T. (2006). Does Corporate Governance Transparency Affect the Accuracy of $\begin{array}{lllll}\text { Analyst Forecast. Accounting and } & \text { Finance, }\end{array}$ http://dx.doi.org/10.1111/j.1467-629X.2006.00191.x

Bhushan, R. (1989). Firm Characteristics and Analysts Following. Journal of Accounting and Economics, 11(2-3), 255-274. http://dx.doi.org/10.1016/0165-4101(89)90008-6 
Bolliger, G., \& Kast, M. (2007). Executive Compensation and Analyst Guidance: The Link Between CEO Pay and Expectations Management. Conflict of Interest, Corporate Governance \& Financial Markets, Chapter 4, 163-167.

Brown, L. D., \& Caylor, M. L. (2005). A Temporal Analysis of Quarterly Earnings Surprises Thresholds: Propensities and Valuation Consequences. The Accounting Review, 80(2), 423-440. http://dx.doi.org/10.2308/accr.2005.80.2.423

Burgstahler, D., \& Dichev, I. (1997). Earnings Management to Avoid Earnings Decreases and Losses. Journal of Accounting and Economics, 24(1), 99-126. http://dx.doi.org/10.1016/S0165-4101(97)00017-7

Burgstahler, D., \& Eames, M. (2006). Management of Earnings and Analysts' Forecasts to Achieve Zero and Small Positive Earnings Surprises. Journal of Business Finance And Accounting, 33(5-6), 633-652. http://dx.doi.org/10.1111/j.1468-5957.2006.00630.x

Bushee, B. (1998). The influence of Institutional Investors on Myopic R\&D Investment Behavior. The Accounting Review, 73(3), 305-333.

Chen, C. R., \& Steiner, T. L. (2000). Tobin's, Managerial Ownership and Analyst Coverage. A nonlinear simultaneous equations mode. Journal of Economics and Business, 52(4), 365-382. http://dx.doi.org/10.1016/S0148-6195(00)00024-2

Cohen, D., Dey, A., \& Lys, T. (2008). Real and Accrual-Based Earnings Management in the Pre- and Post-Sarbanes Oxley Periods. The Accounting Review, 82, 757-787. http://dx.doi.org/10.1016/S0148-6195(00)00024-2

Cohen, J., Krisnamoorthy, G., \& Wright, A. (2010). Corporate Governance in the Post-Sarbanes-Oxley Era: Auditors' Experiences. Contemporary Accounting Research, 27(3), 751-785. http://dx.doi.org/10.1111/j.1911-3846.2010.01026.x

Das, S., Levine, C. B., \& Sivaramakrishnan, K. (1998). Earnings Predictability and Bias in Analysts' Earnings Forecasts. The Accounting Review, 73(3), 277-294.

Dechow, P. M., Sloan, R. G., \& Sweeney, A. P. (1995). Detecting Earnings Management. The Accounting Review, 70(2), 193-225.

Degeorge, F., Patel, J., \& Zeckhauser, R. (1999). Earnings Management to Exceed Thresholds. Journal of Business, 72(1), 1-33. http://dx.doi.org/10.1086/209601

Fuller, R, J., \& Jensen, M. C. (2002). Just Say No to Wall Street. Journal of Applied Corporate Finance, 14(4), 41-46. http//dx.doi.org/10.1111/j.1745-6622.2002.tb00447.x

Grossman, S. J., \& Hart, O. D. (1982). Corporate Financial Structure and Managerial Incentives. The Economics of Information and Uncertainty.

Guttman, L. O., Kandan, O., \& Kandel, E. (2006). A Rational Expectations Theory of the Kink in Earnings Reports. The Accounting Review, 81(4), 811-848.

Imhoff, E. A., \& Lobo, G. J. (1984). Information Content of Analysts' Composite Forecast Revisions. Journal of Accounting Research, 22(2), 541-554. http://dx.doi.org/10.2307/2490663

Jensen, M. C. (2004). The Agency Costs of Overvalued Equity and the Current State of Corporate Finance. European Financial Management, 10(4), 549-565. http//dx.doi.org/10.1111/j.1354-7798.2004.00265.x

Jiang, J. X. (2008). Beating Earnings Benchmarks and the Cost of Debt. The Accounting Review, 83(2), 377-416. http// dx.doi.org/10.2308/accr.2008.83.2.377

Kanagaretnam, K. G., Lobo, G. J., \& Mathieu, R. (2012). CEO Compensation Mix and Analysts' Forecast Accuracy and Bias, Review of Quantitative Finance and Accounting, 38(3), 299-322. http//dx.doi.org/10.1007/s11156-011-0229-0

Kaszniks, R., \& McNichols, M. F. (2002). Does Meeting Expectation Matter? Evidence From Analyst Forecast Revision and Share Prices. Journal of Accounting Research, 40(3), 727-759. http//dx.doi.org/10.1111/1475-679X.00069

Ke, B., \& Ramalingegowda, S. (2005). Do Institutional Investors Exploit Post-Earnings Announcement Drift? Journal of Accounting and Economics, 39(1), 25-53. http//dx.doi.org/10.2139/ssrn.446520

Koh, K., Matsumoto, D. A., \& Rajgopal, S. (2008). Meeting or Beating Analyst Expectations in the Post-Scandals World: Changes in Stock Market Rewards and Managerial Actions. Contemporary 
Accounting Research, 25(4), 1067-98. http//dx.doi.org/10.1506/car.25.4.5

Kross, W., Ro, B., \& Suk, I. (2011). Consistency in Meeting or Beating Expectations and Management Earnings Forecasts. Journal of Accounting and Economics, 51(1-2). 37-57. http://dx.doi.org/10.1016/j.jacceco.2010.06.004

Lopez, T. J., \& Rees, L. (2002). The Effect of Beating and Missing Analysts' Forecasts on the Relation Content of Unexpected Earnings. Journal of Accounting, Auditing and Finance, 17, 155-184. http//dx.doi.org/10.1177/0148558X0201700204

Mande, V., \& Soon, M. (2012). CEO Centrality and Meeting or Beating Analysts' Forecasts. Journal of Business Finance and Accounting, 39(1-2), 82-112. http//dx.doi.org/10.1111/j.1468-5957.2011.02262.x

Matsumoto, D. A. (2002). Management's Incentives to Avoid Negative Earnings Surprises. The Accounting Review, 77(3), 483-514. http://dx.doi.org/10.2308/accr.2001.76.3.313

Matsunaga, S. R., \& Park, C. W. (2001). The Effect of Missing a Quarterly Earnings Benchmark on the CEO's Annual Bonus. The Accounting Review, 76(3), 313-332. http://dx.doi.org/10.2308/accr.2001.76.3.313

McVay, S. V, Nagar, V., \& Tang, V. W. (2006). Trading Incentives to Meet Analysts' Forecasts. Review of Accouting Studies, 11(4), 575-598. http://dx.doi.org/ 10.1007/s11142-006-9017-9

Mikhail, M. B., Walther, B. R., \& Willis, R. H. (1999). Does Forecast Accuracy Matter to Security Analysts? The Accounting Review, 74(2), 185-200. http://dx.doi.org/10.2308/accr.1999.74.2.185

Rickling, M., Rama, D., \& Raghunandan, K. (2013). Repeatedly Meeting-Beating Analysts' Forecasts and Audit Fees, International Journal of Business, 18(2), 119-130.

Shanthikumar, D. M. (2012). Consecutive Earnings surprises: Small and Large Trades Reaction. The Accounting Review, 87(5), 1709-1736. http://dx.doi.org/10.2308/accr-50188

Shleifer, A., \& Vishny, R. W. (1997). A Survey of Corporate Governance. The Journal of Finance, 52(2), 737-783. http://dx.doi.org/10.1111/j.1540-6261.1997.tb04820.x

Shin, J. T. (2005). The Composition of Institutional Ownership and The Structure of CEO Compensation. Working Paper, University of Wisconsin-Madison.

Skinner, D. J., \& Sloan, F. G. (2002). Earnings Surprises, Growth Expectations and Stock Returns or Don't Let an Earnings Torpedo Sink Your Portfolio. Review of Accounting Studies, 7(2-3), 289-312. http://dx.doi.org/10.1023/A:1020294523516

Stulz, R. M. (1990). Managerial Discretion and Optimal Financing Policies. Journal of Financial Economics, 26(1), 3-27. http://dx.doi.org/10.1016/0304-405X(90)90011-N

Tong, Z. (2007). Deviation from Optimal CEO Ownership and Firm Value. Journal of Banking and Finance, 32(11), 2462-2470. http://dx.doi.org/10.1016/j.jbankfin.2008.05.005

Vickers, M. (1999). Ho-hum, another Earnings Surprise. Business Week, 83-84.

Wahal, S., \& McConnell, J. J. (2000). Do Institutional Investors Exacerbate Managerial Myopia? Journal of Corporate Finance, 6(3), 307-329. http://dx.doi.org/10.1016/S0929-1199(00)00005-5

Williams, J. L., \& Sun, H. L. (2011). The Impact of Regulation on Firms' Ability to Habitually Meet or Beat Analysts' Expectations. Research in Accounting Regulation, 23, 188-192. http://dx.doi.org/10.1016/j.racreg.2011.06.012

Xie, B., Davidson, W. N., \& DaDalt, P. J. (2003). Earnings Management and Corporate Governance: The Role of the Board and the Audit Committee. Journal of Corporate Finance, 9, 295-316. http://dx.doi.org/10.1016/S0929-1199(02)00006-8

\section{Notes}

Note 1. Previous studies used also repeatedly, persistently or habitually to describe repetitive patterns of meeting analysts' forecasts.

Note 2. Analysts earnings forecasts are generally used as a proxy for earnings expectations.

Note 3. Small refers to ownership and not to the institutional characteristics.

Note 4. Total compensation is the sum of all CEO compensation components including salary, bonus, options awarded and all other annual and long term compensation. Option value is the potential realized value at assumed annual rate of stock appreciation of $5 \%$. 
Note 5. Stock ranked 1 is likely to outpace the year-ahead market. Those ranked 5 are expected to underperform most stocks over the next 12 months.

Note 6. The NASD Rule 2711 (Research Analysts and Research Reports) and the amended NYSE Rule 472 (Communications with the Public) .

\section{Copyrights}

Copyright for this article is retained by the author(s), with first publication rights granted to the journal.

This is an open-access article distributed under the terms and conditions of the Creative Commons Attribution license (http://creativecommons.org/licenses/by/3.0/). 